\title{
Efficacy of Selected Insecticides and Botanicals in the Control of Field Insect Pest of Okra (Abelmoschus Esculentus) in Akure
}

\author{
Benson, G. A. S \\ Department of Crop Production and Horticulture, Lagos State Polytechnic, Ikorodu. Lagos State. Nigeria
}

*Corresponding Author: Benson, G. A. S, Department of Crop Production and Horticulture, Lagos State Polytechnic, Ikorodu. Lagos State. Nigeria.

\begin{abstract}
A randomized complete block field experiment was conducted to evaluate the insecticidal efficacy of selected synthetic insecticides and botanicals for the control of insect pests of okra (Abelmoschus esculentus) L Moench at the Teaching and Research Farm of The Federal University of Technology, Akure $\left(7016^{\prime} \mathrm{N}, 15012^{\prime} \mathrm{E}\right)$. The experiments consisted of four rates $(50,75,100$, and 125\%) of lambda-cyhalothrin, dichloropyrivos and carbaryl and two extraction methods comprising of hot and cold extracts of Piper guineense, Allium sativum and Azadirachtaindica including their mixtures. The treatments were sprayed twice and thrice while assessments of insecticidal efficacy based on Henderson Tilton formular was conducted at 2, 4 and 6 week after treatment application. Insect counts were collected and percent efficacy calculated. Result obtained shows that there was a general decline in insect population as the insecticide application continued and all the biocides were significantly $(P<0.05)$ toxic to the flea beetles than the control. Carbaryl performance exceeded all other insecticides in the parameter measured. Although the performance of the botanicals is not as good as synthetic insecticide, it was better than the untreated control plot. It is concluded that A. indica, P. guineense and A. sativum (in order of importance) can be used as an alternative to the synthetic insecticides tested in this study for the control of flea beetle and other insect pests on okra.
\end{abstract}

Keywords: Okra insect pest control, synthetic insecticides, botanicals and efficacy.

\section{INTRODUCTION}

Okra (Abelmoschusesculentus (L) Moench) is one of the most widely grown and consumed vegetables. It forms an essential part of diet for its calcium and iodine contents as well as the mucilaginous properties of its fruit. Okra is also a good source of vitamins A, B and C. Okra is also a potential candidate as a biodiesel feedstock. The crop is battled with pests. Oladimeji et al. (2010) described the flea beetles as the most injurious insects on okra. Flea beetles are presently being controlled with insecticides among which lambda-cyhalothrin (Karate), a synthetic pyrethroid is known to be effective. However, the associated problems of synthetic insecticides have called for a renewed interest in the botanicals. Also, consumer demand for organically produced foods is on the increases and scientific research on the use of botanical pesticides is now gaining momentum (Nas, 2004). This research work evaluates the efficacies of commonly used organophosphorus (Chloropyrifos), carbamate (Carbofuran), synthetic pyrethroid (Lambda-cyhalothrin) and the potentials of aqueous extracts of three botanicals obtained from seeds of Azadirachtaindica, Piper guineense and Allium sativumpaste in the control of insect pests of okra. The specific objectives are to assess the level of insect pests infestation on okra in response to the various insecticide treatments; to determine the efficacy of the selected insecticides and botanicals in the control of insect pests of okra; and to determine the separate and combined effects of the botanicals under study in the control of insect pests on okra.

\section{MATERIALS AND METHODS}

The research was conducted at the Experiment Station of the Department of Crop, Soil and Pest Management of the Federal University of Technology, Akure in the 2014 early raining season. The site lies roughly between latitude $7^{0} 16^{1}$ northand longitude $5^{0} 12^{1}$ east of Greenwich meridian. It is in the rainforest zone with alfisol soil type. The rainfall pattern is similar to that of any humid tropical climate, characterized by two peaks. The experimental site was ploughed twice with a two-week 
interval between the first and the second and stumped. The site was pegged and lined out in a dimension of $3 \mathrm{~m} \times 2 \mathrm{~m}$ to accommodate one hundred and forty-nine beds. One (1m) metre discard was left between beds and replicates to ease management operations and to guide against spray drift from plot to plot. The gross experimental plot size is $148 \mathrm{~m} \mathrm{x} 13 \mathrm{~m}\left(1924 \mathrm{~m}^{2}\right)$ and the net experimental plot area is $6 \mathrm{~m}^{2}(3 \mathrm{~m} \times 2 \mathrm{~m})$. The experimental design used was Randomised Complete Block Design. The data collected were subjected to statistical analysis using the Statistical Package for Social Sciences (SPSS) software. Means where significant were separated using Duncan Multiple Range Test (DMRT). Seeds of an early maturing okra variety (NHae 47-4) obtained from Ondo State Agricultural Input Supply Agency, Ondo Road, Akure were used in this work. Seeds were sown at a spacing of $60 \mathrm{~cm} \times 50 \mathrm{~cm}$ with two seeds per hole. The stands was thinned to one at 2 weeks after emergence ( 2 WAE) - giving a plant population of 25 plants per plot and an equivalent of 41666.6plants/ha. Supplying was done 2 weeks after emergence. Weeding operations were carried out at 2 weeks after sowing of okra seed. Subsequent weeding was done as the weed emerged. Three synthetic insecticides, one each from the organophosphate, carbamate and pyrethroid groups were applied at two rates within and two rates outside manufacturer's recommendation. Botanicals obtained from $50 \mathrm{~g}$ of plant materials Azardirachtaindica, fruit extract of Piper guineense and bulb extract of Allium sativum grinded in a mortar and pestle and blender and diluted with $1 \mathrm{~L}$ of distilled water and later filtered to create the stock solution and mixture of the botanicals at $25 \mathrm{~g}$ each/ per litre of water were also applied. Extraction using the hot and cold water was adopted from the method of Omoloye et al. (2002) and Obadofin et al. (2006). The chemical insecticides and botanicals were sprayed at 2 weeks and 4 weeks after emergence and half at 6 weeks after emergence using 16-litre capacity knapsack sprayers dedicated to the different treatments to test for their effects on pest. The knapsack sprayers were calibrated using the volume rate method. Insect count in relation to the insecticides tested at varying rates and extraction methods were done prior to insecticide application at 2, 4 and 6 weeks after planting. Their percentage efficacy of the insecticides was calculated using the Handerson method $(1-\mathrm{Ta} / \mathrm{Ca} \times \mathrm{Cb} / \mathrm{Tb}) \times 100$. The value obtained was transformed with the Arc Sine transformation formulae (Arc Sine $\sqrt{ } \mathrm{X} / 100$ ), where $X=\%$ efficacy.

Table1. Percent efficacy of insecticide treatments on insect count on okra at 2, 4 and 6 weeks after treatment (WAT).

\begin{tabular}{|c|c|c|c|c|c|}
\hline \multirow[t]{2}{*}{ Insecticide } & \multirow{2}{*}{$\begin{array}{l}\text { Conc. } \\
(\%)\end{array}$} & \multirow{2}{*}{$\begin{array}{l}\text { Frequency of } \\
\text { Application }\end{array}$} & \multicolumn{3}{|c|}{ Weeks after treatment } \\
\hline & & & 2 & 4 & 6 \\
\hline \multirow{4}{*}{ Lambda-cyhalothrin } & 125 & 2 & $41.91 b c$ & $53.24 b$ & $74.01 \mathrm{~b}$ \\
\hline & 100 & 2 & $30.89 \mathrm{dc}$ & $51.78 \mathrm{~b}$ & $54.9 \mathrm{~d}$ \\
\hline & 75 & 2 & $24.08 \mathrm{de}$ & $40.38 \mathrm{c}$ & $46.79 \mathrm{de}$ \\
\hline & 50 & 2 & $18.72 \mathrm{f}$ & $31.28 \mathrm{~b}$ & $39.44 \mathrm{ef}$ \\
\hline \multirow[t]{4}{*}{ Dichlorvos } & 125 & 2 & $38.87 \mathrm{bc}$ & $46.53 \mathrm{bc}$ & $54.56 \mathrm{~d}$ \\
\hline & 100 & 2 & $35.93 \mathrm{bc}$ & $56.44 \mathrm{ab}$ & $43.51 \mathrm{e}$ \\
\hline & 75 & 2 & $26.12 \mathrm{de}$ & $45.73 \mathrm{bc}$ & $40.00 \mathrm{ef}$ \\
\hline & 50 & 2 & $29.79 d$ & $40.89 \mathrm{c}$ & $36.19 \mathrm{ef}$ \\
\hline \multirow[t]{4}{*}{ Carbaryl } & 125 & 2 & $48.28 \mathrm{a}$ & $59.63 \mathrm{ab}$ & $81.10 \mathrm{a}$ \\
\hline & 100 & 2 & $51.10 \mathrm{a}$ & $64.19 a$ & $78.53 \mathrm{ab}$ \\
\hline & 75 & 2 & $42.99 \mathrm{ab}$ & $49.75 \mathrm{bc}$ & $56.46 \mathrm{~cd}$ \\
\hline & 50 & 2 & $46.49 \mathrm{ab}$ & $53.81 \mathrm{~b}$ & $51.55 \mathrm{~d}$ \\
\hline Azadirachtaindica hot & 100 & 2 & $39.78 \mathrm{bc}$ & $51.86 \mathrm{~b}$ & $51.48 \mathrm{~d}$ \\
\hline Azadirachtaindica cold & 100 & 2 & $43.39 \mathrm{ab}$ & $58.95 \mathrm{ab}$ & $51.01 \mathrm{~d}$ \\
\hline Allium sativum hot & 100 & 2 & $34.54 \mathrm{bc}$ & $56.82 \mathrm{ab}$ & $54.33 \mathrm{~d}$ \\
\hline Allium sativum cold & 100 & 2 & 26.94de & $34.04 \mathrm{~d}$ & 48.31de \\
\hline Piper guineense hot & 100 & 2 & $40.77 \mathrm{bc}$ & $44.68 \mathrm{c}$ & 47.80de \\
\hline Piper guineense cold & 100 & 2 & $46.95 \mathrm{ab}$ & $51.36 \mathrm{~b}$ & 49.91de \\
\hline Azad + Alli hot & $50: 50$ & 2 & $43.56 \mathrm{ad}$ & $43.43 c$ & $50.98 \mathrm{~d}$ \\
\hline Azad + Alli cold & $50: 50$ & 2 & $39.70 \mathrm{bc}$ & $51.16 \mathrm{~b}$ & $58.45 \mathrm{~cd}$ \\
\hline Azad + Pipe hot & $50: 50$ & 2 & $38.88 \mathrm{bc}$ & $47.55 \mathrm{bc}$ & $53.48 \mathrm{~d}$ \\
\hline Azad + Pipe cold & $50: 50$ & 2 & $39.75 b c$ & $50.52 \mathrm{~b}$ & $57.13 \mathrm{~cd}$ \\
\hline Alli + Pipe hot & $50: 50$ & 2 & $27.58 \mathrm{~d}$ & $39.06 \mathrm{cb}$ & $45.91 \mathrm{de}$ \\
\hline Alli + Pipe cold & $50: 50$ & 2 & $39.21 b c$ & $44.19 \mathrm{c}$ & $41.55 \mathrm{e}$ \\
\hline \multirow[t]{4}{*}{ Lambda-cyhalothrin } & 125 & 3 & $43.05 \mathrm{ab}$ & $47.50 \mathrm{bc}$ & $58.09 \mathrm{~cd}$ \\
\hline & 100 & 3 & $28.61 \mathrm{de}$ & $56.03 \mathrm{ab}$ & $69.76 \mathrm{bc}$ \\
\hline & 75 & 3 & $36.05 \mathrm{bc}$ & $41.11 \mathrm{c}$ & $56.11 \mathrm{~cd}$ \\
\hline & 50 & 3 & $40.45 \mathrm{bc}$ & $49.44 \mathrm{bc}$ & 49.66de \\
\hline
\end{tabular}


Efficacy of Selected Insecticides and Botanicals in the Control of Field Insect Pest of Okra (Abelmoschus Esculentus) in Akure

\begin{tabular}{|l|l|l|l|l|l|}
\hline \multicolumn{7}{|c|}{} \\
\hline Dichlorvos & 125 & 3 & $46.24 \mathrm{a}$ & $49.10 \mathrm{bc}$ & $57.25 \mathrm{~cd}$ \\
\hline & 100 & 3 & $47.92 \mathrm{a}$ & $36.18 \mathrm{~cd}$ & $41.99 \mathrm{e}$ \\
\hline & 75 & 3 & $41.32 \mathrm{ab}$ & $38.06 \mathrm{~cd}$ & $51.88 \mathrm{~d}$ \\
\hline Carbaryl & 50 & 3 & $23.45 \mathrm{de}$ & $45.92 \mathrm{bc}$ & $49.72 \mathrm{de}$ \\
\hline & 125 & 3 & $46.84 \mathrm{a}$ & $59.72 \mathrm{ab}$ & $80.00 \mathrm{ab}$ \\
\hline & 100 & 3 & $36.78 \mathrm{bc}$ & $64.38 \mathrm{a}$ & $78.15 \mathrm{ab}$ \\
\hline & 75 & 3 & $39.53 \mathrm{bc}$ & $55.47 \mathrm{ab}$ & $70.96 \mathrm{~b}$ \\
\hline Azadirachtaindica hot & 50 & 3 & $37.84 \mathrm{bc}$ & $42.72 \mathrm{c}$ & $74.92 \mathrm{~b}$ \\
\hline Azadirachtaindica cold & 100 & 3 & $50.04 \mathrm{a}$ & $61.99 \mathrm{a}$ & $64.73 \mathrm{c}$ \\
\hline Allium sativum hot & 100 & 3 & $33.60 \mathrm{bc}$ & $45.25 \mathrm{bc}$ & $43.59 \mathrm{e}$ \\
\hline Allium sativum cold & 100 & 3 & $44.09 \mathrm{ab}$ & $51.20 \mathrm{~b}$ & $59.40 \mathrm{~cd}$ \\
\hline Piper guineense hot & 100 & 3 & $35.12 \mathrm{bc}$ & $49.08 \mathrm{bc}$ & $55.86 \mathrm{~cd}$ \\
\hline Piper guineense cold & 100 & 3 & $35.45 \mathrm{bc}$ & $43.00 \mathrm{c}$ & $44.03 \mathrm{e}$ \\
\hline Azad + Alli hot & 100 & 3 & $28.10 \mathrm{de}$ & $44.23 \mathrm{c}$ & $48.63 \mathrm{de}$ \\
\hline Azad + Alli cold & $50: 50$ & 3 & $43.51 \mathrm{ab}$ & $41.65 \mathrm{c}$ & $41.56 \mathrm{e}$ \\
\hline Azad + Pipe hot & $50: 50$ & 3 & $48.43 \mathrm{a}$ & $53.95 \mathrm{~b}$ & $50.86 \mathrm{~d}$ \\
\hline Azad + Pipe cold & $50: 50$ & 3 & $40.42 \mathrm{bc}$ & $47.98 \mathrm{bc}$ & $46.18 \mathrm{de}$ \\
\hline Alli + Pipe hot & $50: 50$ & 3 & $32.88 \mathrm{bc}$ & $43.69 \mathrm{c}$ & $44.59 \mathrm{e}$ \\
\hline Alli + Pipe cold & $50: 50$ & 3 & $38.66 \mathrm{bc}$ & $48.02 \mathrm{bc}$ & $48.26 \mathrm{de}$ \\
\hline Conrol (Untreated) & $50: 50$ & 3 & $27.44 \mathrm{de}$ & $36.41 \mathrm{~cd}$ & $42.65 \mathrm{e}$ \\
\hline Azadirachtaindica hot & - & & $0 \mathrm{f}$ & $0 \mathrm{e}$ & $0 \mathrm{f}$ \\
\hline
\end{tabular}

\section{RESULTS AND DISCUSSION}

Tables 1 and 2 summarized the efficacy of insecticide treatments on insect counts monitored at 2, 4 and 6 weeks after treatment (WAT) and their correlations. Significant differences in percent efficacy on insect counts were noted among varying rates of the synthetic insecticides, hot and cold extracts of the botanical insecticides and their combinations regardless of their frequency of application throughout the evaluation period. All treatments gave significant insect control compared to untreated control, with 2 sprays of carbaryl at $100 \%$ concentration providing the best control at 4 WAT, although this was not significantly different from most of the treatments. No statistically detectable difference in percent efficacy on insect counts occurred amongst the treatments due to frequency of application. However, treatments involving two sprays of carbaryl generally provided better control of insect pests than those involving three sprays. In contrast, three applications of lambda-cyhalothrin and dichlorvos were more effective than two applications in reducing insect pest populations in the plots at 4 WAT. At 6 WAT, all treatments gave significant control with 2 sprays of carbaryl concentrations producing the overall best result while a mixture of cold water extract of Azadirachtaindica and Allium sativum gave the best result from the botanicals and their mixtures. Regressing percentage insecticidal efficacy (Y) against increasing concentration levels of synthetic insecticides (X) shows positive correlation with prediction equations shown in Table 2.

Table2. Correlation between percentage efficacies of synthetic pesticides $(Y)$ and concentration levels $(X)$ and their regression equations.

\begin{tabular}{|c|c|c|c|c|c|c|c|}
\hline \multirow{3}{*}{ Insecticides } & \multirow{3}{*}{$\begin{array}{l}\text { Freq. } \\
\text { of } \\
\text { appl. }\end{array}$} & \multicolumn{6}{|c|}{ Weeks after treatment } \\
\hline & & \multicolumn{2}{|c|}{2} & \multicolumn{2}{|l|}{4} & \multicolumn{2}{|l|}{6} \\
\hline & & $\begin{array}{l}\text { Corr. } \\
\text { coeff. } \\
\text { (r) }\end{array}$ & $\begin{array}{l}\text { Regression } \\
\text { equation }\end{array}$ & $\begin{array}{l}\text { Corr. } \\
\text { coeff. } \\
\text { (r) }\end{array}$ & Regression equation & $\begin{array}{l}\text { Corr. } \\
\text { coeff. } \\
\text { (r) }\end{array}$ & Regression equation \\
\hline $\begin{array}{l}\text { Lambda- } \\
\text { cyhalothrin }\end{array}$ & 2 & +0.99 & $Y=2.167+0.306 X$ & +0.96 & $Y=17.122+0.309 X$ & +0.97 & $Y=14.648+0.447 X$ \\
\hline Dichlorvos & 2 & +0.83 & $Y=19.71+0.148 X$ & +0.55 & $Y=37.727+0.011 X$ & +0.96 & $Y=23.048+0.234 X$ \\
\hline Carbaryl & 2 & +0.51 & $Y=42.50+0.054 X$ & +0.64 & $Y=45.680+0.128 X$ & +0.95 & $Y=28.158+0.443 X$ \\
\hline $\begin{array}{l}\text { Lambda- } \\
\text { cyhalothrin }\end{array}$ & 3 & +0.007 & $\mathrm{Y}=36.91+0.001 \mathrm{X}$ & +0.19 & $Y=45.335+0.036 X$ & +0.60 & $Y=44.776+0.156 X$ \\
\hline Dichlorvos & 3 & +0.86 & $\mathrm{Y}=13.49+0.300 \mathrm{X}$ & +0.16 & $Y=39.634+0.031 X$ & +0.26 & $\mathrm{Y}=45.765+0.051 \mathrm{X}$ \\
\hline Carbaryl & 3 & +0.69 & $Y=31.76+0.097 X$ & +0.83 & $\mathrm{Y}=34.604+0.240 \mathrm{X}$ & +0.73 & $\mathrm{Y}=68.157+0.090 \mathrm{X}$ \\
\hline
\end{tabular}

The study clearly shows that $A$. indica, $P$. guineense and $A$. sativum are insecticidal to insect pests on okra and particularly Podagrica spp. as all the synthetic insecticides and botanicals tested tend to inhibit reproduction and development of the pest at the concentrations and extraction methods tested. The study also provides empirical evidence that $A$. indica, $P$. guineense and A. sativum compared 
favourably with the tested synthetic insecticides in reducing or preventing insect pest infestation and thereby reducing damages to okra leaves. The study has further corroborated the reports of other researchers that products from neem tree including their extracts can be used to control field insect pests on okra. This work has also demonstrated the sensitivity of okra to carbaryl and that it may be suggested for use as an indicator for detection of phytotoxicity of insecticides on leafy vegetables. The results of this study have confirmed the potentials of the synergistic effect of mixtures of $A$. indica, $P$. guineense and A. sativum in the protection of okra plant from pest attack. The outcome of this work is in consonance with great scientist (Lale, 2001; Ofuya, 2003) who opined that a view plants in the Nigerian flora with confirmed biological efficacies against species of stored product insects were sufficiently insecticidal to merit scientific formulation.

The activity of neem have been attributed to various chemical compound which include diterpenoids, triterpenoids, trinotriterpenoids D-lactose, hexanortrititerpenoids, octanortiterpenoids and enneanoorpenoids numbering over 250. These bioactive compounds are said to act in concert thereby giving no room for development of pest resistance. They exhibit significant antifeedant, pesticidal, microbial and inert growth disrupting properties. They also incite sterility in some insect, impair egg fertility, deter oviposition and have insect repellency (Kraus, 2002). Piperguineense has also been found to contain isobutylamides, a plant secondary compound that act as neurotoxicity in insect (Adedire and Ajayi, 1996, Ofuyaet al, 2007). Allium formulates also have repellent activity thus protecting plant leaves. Also A. sativum has been reported to have repellent, antifeedant, fungicidal, bactericidal and nematicidal properties (Mason and Lenz, (1997). The work supports the findings of Basedow et al (2002) who reported that A. indica-based products were effective, or even more effective than synthetic insecticides in the control of aphids and whiteflies. This work is in favour of allium is supported by Arannilewa et al. (2006) who reported the potency of A. ringes and A. sativum on adult mortality and adult emergence of Sitophilus zeamais. This work also corroborates the work of Lale and Mustapha (2000) and Ehisianya et al. (2012) who stated that neem products performed equally or sometimes better than some synthetic insecticides.

\section{CONCLUSION AND RECOMMENDATIONS}

Okra plant is susceptible to an array of pests ranging from sucking pests - Aphids (Aphis gossypii) and White fly (Bermisatabacci), Hoppers, Cotton stainer, Flea beetle (Podagricaspp.) from early stage to maturity. Within the period of this study, there were significant differences in the level of infestation on okra by the okra flea beetle. Based on findings from this work, it is can be recommended that the botanical used in this study can serve as a good substitutes to the synthetic insecticides. Lesser rates to $50 \mathrm{~g}$ of plant materials per litre of water may also be tested to determine the most appropriate rate and to reduce cost of treatment materials. A synergist may be added to improve the performance of the botanicals. As there is an extent to which the concentration of a pesticide could be increased to achieve a better result and since total elimination of pest is neither possible nor necessary, it is better to maintain a concentration that would keep the population of the pest at a minimum. Therefore a 75$100 \%$ of manufactures' recommendation for the synthetic insecticides should be adhered to as concentration below or above these levels is either ineffective or phytotoxic to plant when it is economical to do so.

\section{REFERENCES}

[1] Abbot, W. S. (1925): A method of computing the effectiveness of an insecticide. Journal of Economic Entomology 18, $265-267$.

[2] Adedire C. O and Lajide L. (2000). Toxicity and oviposition deterrency of activities of powders and extracts of pepper fruit plant Dennettiatripetata Baker to the pulse bettle, Callosobruchusmaculatus (F) (ColeopteraBruchidae ). Ent. Soc. Niger, Occas. Publ.32: 199-206.

[3] Ahmed O. and M. A. Kannike (2010): Comparative studies on the efficacy of neem, basil leaf extract and synthetic insecticide, Lambda- cyhalothrin against Podagrica spp. on okra. African Journal of Microbiology Research Vol 4(1): 033-037.

[4] Arannilewa S. T., T. E. Ekankene and J. C. Akinneye (2006): Laboratory evaluation of four medicinal plants as protectant against the maize weevil Sitophilus zeamais. African Journal of Biotechnology. Vol 5(21): 2032-2036. 
[5] Basedow, T., H. R. Obiewatsch, J. A. Bernal Vega, S, Kollmann and C. M. Y. Nicol (2002): Control of Aphids and Whiteflies (Hom: Aphididae and Alleyrodidae) with different neem preparations in laboratory, greenhouse and field: Effects and limitations. J. Plant Dis. Prot. 109:612 - 623.

[6] Ehisianya C.N, Ogbonna M. C., Lale N. E. S. and Umeozor, O. C. (2012):Economics of Neem (Azadirachtaindica A. Juss) seed oil for the management of Cylaspuncticollis (Boheman) (Coleoptera : Brentidae) infesting sweet potato in Nigeria. Nigeria Journal of Entomology Vol 28: 82 - 92.

[7] Kraus, W. (2002): Biologically active ingredient. Azadirachtins and triterpenoids. In Schmutterer H. $2^{\text {nd }}$ ed.. The Neem Tree: Azadirachtaindica A. Juss and other meliacious plant. Sources of unique natural products for integrated pest management, medicine, industry and other purposes. $2^{\text {nd }}$ Edition, Neem Foundation. Mumbai, India. Pg 39-78.

[8] Lale N. E. S. and Mustapha .A. (2000): Efficacy and acceptability of Neem Azadirachtaindicaseed oil and pirimorphos methyl applied on three storage devices for control of Callosobruchus Planzenkrankheitan Pflanzenschutz 197:399-405.

[9] Mason J. H. and Lenz G (1997): Repellency of Garlic extracts to European Stiriings. Crop Protection. Vol 16 Pp 107-108.

[10] Nas M. N. (2004): In vitro studies on some natural beverages as botanical pesticides against Erwiniaamylovora and Curobacterium flacumfaciensis subsp. Poinsetteae. Turk. J. Agric 28: 57-61.

[11] Obadofin. A. A., Dada, O. A. and Oyebode. B. A. (2006): Control of insect pests of cowpea (thrips and bugs) with extracts of Azadirachtaindica and Ocimumgratissimum. Journal of Applied Science and Technology, 3(2): 167-177.

[12] Ofuya, T. I. (2003). Beans, insect and man. Inaugural Lecture Series 35. The Federal University of Technology, Akure, Nigeria. 45pp.

[13] Ofuya, T. I., Olotuah, O. F. and Aladesanwa, R. D. (2007). Potential of Eugeniaaromatic, Baill dry flower buds and Piperguineense Schum and Thonn. Dry fruit formulated with three organic flours for controlling Callosobruchusmaculatus (Fabricius) (Coleoptera:Bruchidae). Nigerian Journa of Entomology 24: 98 106.

[14] Oladimeji. A. O and Musa A.(2010). Comparative studies on the efficacy of neem, basil leaf extracts and synthetic insecticide, lambda-cyhalothrin, against Podagrica spp. on okra. African Journal of Microbiology Research Vol 4 (1) 033-037.

[15] Omoloye, A. A., J. A. Odebiyi, and C. T. Williams (2002). Tolerance indicators and responses of rice cultivars to infestation of the African rice gall midge. Journal of Agricultural Science 138: 1-6.

Citation: Benson, G.A.S, " Efficacy of Selected Insecticides and Botanicals in the Control of Field Insect Pest of Okra (Abelmoschus Esculentus) in Akure", International Journal of Forestry and Horticulture (IJFH), vol. 3, no. 4, p. 1-5, 2017. http:// dx.doi.org/10.20431/2454-9487.0304001

Copyright: (C) 2017 Authors. This is an open-access article distributed under the terms of the Creative Commons Attribution License, which permits unrestricted use, distribution, and reproduction in any medium, provided the original author and source are credited. 